\title{
THE EFFECT OF WATER EXTRACT FROM WILD THYME ON COLORADO POTATO BEETLE FEEDING
}

\author{
Milena Rusin'1, Janina Gospodarek1 ${ }^{1}$ Barbara Biniaś ${ }^{1}$ \\ 1 University of Agriculture in Krakow, Al. Mickiewicza 21, 31-120 Kraków, Poland, e-mail: milena_rusin@wp.pl
}

Received: 2016.05 .23

Accepted: 2016.08.08

Published: 2016.09.30

\begin{abstract}
The aim of this study was to determine the effect of water extracts prepared from fresh and dry matter of wild thyme (Thymus serpyllum L.) on feeding adults and larvae of Colorado potato beetle (Leptinotarsa decemlineata Say.). The experiment was conducted in the laboratory, in six replicates. Dry extracts were prepared at concentration of $2 \%, 5 \%$ and $10 \%$, while the fresh plant at concentration of $10 \%, 20 \%$ and $30 \%$. Feeding intensity assessment was conducted by dipping leaves of potato in respective solutions of the extracts and determining the mass of food consumed by adults and larvae, and changes of larvae body weight once daily. In addition, absolute deterrence index and palatability index were calculated. The results of the experiment showed that for an efficient limitation of the feeding adult Colorado potato beetles, an extract from dry matter of wild thyme with a concentration of at least $10 \%$ should be used. L4 larvae appear to be considerably more susceptible to the effect of T. serpyllum extract. In their case, an efficient limitation of the feeding, as well as body weight gain can be obtained using extracts from both dry and fresh matter, at concentrations of over $5 \%$ for dry matter and over $20 \%$ for fresh matter. With the increase of extract concentration, the value of the calculated palatability index decreases, and the deterrence index value increases.
\end{abstract}

Keywords: water extracts, Colorado potato beetle, wild thyme, biological control

\section{INTRODUCTION}

Wild thyme (Thymus serpyllum L.) is a perennial plant of the deadnettle family (Lamiaceae), exhibiting a number of therapeutic properties: antioxidant, hypotensive [Kulisic et al. 2005, Mihailovic-Stanojevic et al. 2013], expectorant and antiseptic [Abu-Darwish et al. 2009]. Moreover, it is a melliferous plant and it is also used in the perfume and catering industry. Its composition contains approximately $0.5 \%$ of essential oil, bitter compounds, mineral salts but also tannins and flavonoids [Raal et al. 2004, Sipailiene et al. 2006, Paaver et al. 2008], which provide potential possibilities for the use of extracts and essential oils from the plant for the limitation of the feeding of crop pests. Biological methods of plant protection against pests are becoming increasingly common due to their safety for the natural environment and the requirements set for the integrated and organic farming, and their efficiency is comparable to that of chemical products [Tscharntke et al. 2005].

Colorado potato beetle (Leptinotarsa decemlineata Say.) is a common pest of potato cultivations and of other plants of the Solanaceae family, able to cause considerable yield losses [Popova 2014, Alkan et al. 2015]. Chemical products are most commonly used in order to protect plants against the feeding of this pest, however, due to the threat posed to the natural environment and the fact of pest immunization to the active substances contained in these compounds [Szendrei et al. 2012] it is important to look for non-chemical methods of controling the pest.

The objective of the conducted study was determination of the effect of extracts prepared from dry as well as fresh matter of wild thyme in different concentrations on the feeding of adult indi- 
viduals and L4 larvae of Colorado potato beetle. Moreover, values of the absolute deterrence index and palatability index were calculated for both analyzed developmental stages.

\section{MATERIAL AND METHODS}

The experiment was conducted in the laboratory, in six replicates. Fresh leaves of potato, adults and larvae of Colorado potato beetle used for the analysis at the end of June 2015 were collected.

Extracts from dry matter of wild thyme were prepared at concentration assumed conventionally as $2 \%, 5 \%$ and $10 \%$ (dried plants + cold redistilled water in proportions of $2: 100,5: 100$ and $10: 100)$ and at concentration of $10 \%, 20 \%$ and $30 \%$ for fresh matter (fresh above-ground parts of plants + cold redistilled water in proportions of $10: 100,20: 100$ and $30: 100$ ). For the period of 24 hours the extracts were stored in the dark, and then filtered through filter papers and immediately used for the conduct of the experiment. The test was conducted on Petri dishes, and the substrate consisted of moist filter paper. Potato leaves were soaked for 3 seconds in adequate plant extracts and in distilled water used as control, and then dried at room temperature. In each dish one leaf of potato, suitable for a specific object was placed and then one adult of Colorado potato beetle and separately two larvae (L4 stage) were introduced.

In order to determine the effect of extracts of wild thyme on Colorado potato beetle the mass of food consumed by adults and larvae and larvae weight gain once daily were established. In addition, the values of palatability index as the ratio of the percentage mass of leaves consumed in individual objects to the percentage mass of leaves consumed in the control were calculated. Furthermore, absolute deterrence index which takes into account the relationship between the mass of leaves consumed in the individual objects and the mass of leaves consumed in the control was established:

$$
B w d=[(K-T):(K+T)] \cdot 100
$$

where: $B w d-$ absolute deterrence index.

$K$ - mass of leaves consumed in control [mg].

$T$ - mass of leaves consumed in individual objects [mg] [Kiełczewski 1979].

The obtained results were subjected to analysis by STATISTICA 10.0 software. The significance of differences between the means were tested by univariate analysis of variance, and the means were differentiated by Fisher's LSD test at $\alpha=0.05$.

\section{RESULTS AND DISCUSSION}

The extract prepared from dry matter of wild thyme in its highest concentration $(10 \%)$ on all dates of the conducted observations caused a significant decrease of the leaf mass consumed by Colorado potato beetle imago (Table 1). During the first observation, the mass of food consumed by the analyzed pests on the object was almost $20 \mathrm{mg}$ lower than in the control object, whereas during last observation - over $50 \mathrm{mg}$ lower. The remaining extracts prepared from both fresh as well as dry matter of wild thyme did not have a significant effect on the analyzed parameter and the consumed leaf mass on these objects was similar to the control. Moreover, it was observed, that along with the increase concentrations of

Table 1. The effect of water extracts prepared from dry and fresh matter of wild thyme on the leaf mass consumed by adult of Colorado potato beetle [mg].

\begin{tabular}{|c|c|c|c|c|c|}
\hline \multirow{2}{*}{ Object } & \multicolumn{5}{|c|}{ Time } \\
\cline { 2 - 6 } & $12 \mathrm{~h}$ & $24 \mathrm{~h}$ & $36 \mathrm{~h}$ & $48 \mathrm{~h}$ & $60 \mathrm{~h}$ \\
\hline C & $80,2^{\mathrm{b}^{\mathrm{b}}}$ & $95,6^{\mathrm{b}}$ & $126,8^{\mathrm{b}}$ & $153,8^{\mathrm{b}}$ & $189,2^{\mathrm{b}}$ \\
\hline DM 2\% & $77,9^{\mathrm{ab}}$ & $95,1^{\mathrm{b}}$ & $123,5^{\mathrm{b}}$ & $155,1^{\mathrm{b}}$ & $185,4^{\mathrm{b}}$ \\
\hline DM 5\% & $75,6^{\mathrm{ab}}$ & $89,4^{\mathrm{b}}$ & $124,8^{\mathrm{b}}$ & $142,8^{\mathrm{b}}$ & $179,8^{\mathrm{b}}$ \\
\hline DM 10\% & $62,8^{\mathrm{a}}$ & $85,6^{\mathrm{a}}$ & $101,3^{\mathrm{a}}$ & $119,3^{\mathrm{a}}$ & $135,2^{\mathrm{a}}$ \\
\hline FM 10\% & $82,4^{\mathrm{b}}$ & $102,2^{\mathrm{b}}$ & $131,8^{\mathrm{b}}$ & $150,8^{\mathrm{b}}$ & $192,5^{\mathrm{b}}$ \\
\hline FM 20\% & $80,7^{\mathrm{b}}$ & $93,4^{\mathrm{ab}}$ & $117,9^{\mathrm{ab}}$ & $146,2^{\mathrm{b}}$ & $177,8^{\mathrm{b}}$ \\
\hline FM 30\% & $77,8^{\mathrm{ab}}$ & $90,8^{\mathrm{ab}}$ & $114,8^{\mathrm{ab}}$ & $143,6^{\mathrm{b}}$ & $178,1^{\mathrm{b}}$ \\
\hline
\end{tabular}

C - control, DM - dry matter, FM - fresh matter.

* Values for individual terms of observations marked by different letters are statistically different $(\alpha=0.05)$ 
analyzed extracts, their negative influence on the analyzed pests also increases.

After 12 hours from the establishment of the experiment, only the extract prepared from dry matter with $10 \%$ concentration caused a significant decrease of leaf mass consumed by the Colorado potato beetle larvae (Table 2). However, during the second observation it was noticed that the extracts prepared from both dry as well as fresh matter in two highest concentrations (respectively $5 \%$ and $10 \%$ and $20 \%$ and $30 \%$ ) significantly limited the feeding of the pest larvae and this state was maintained until the end of the experiment. In the case of the extracts from dry matter, the leaf mass consumed by larvae on these objects after 60 hours was approximately $25 \mathrm{mg}$ lower than in the control object, whereas in the case of fresh matter extracts - approximately $35 \mathrm{mg}$ lower.

The available literature does not contain information on the effect of water extracts from wild thyme on the feeding of crop pests, however, few data can be found on the effect of essential oils obtained from the analyzed plant. In their study, Regnault-Roger et al. [1993] demonstrated, that out of 22 tested essential oils, the wild thyme oil limited the feeding of bean weevil $A c$ - anthoscelides obtectus Say. to the greatest extent, as well as caused the highest increase of mortality in the species. Furthermore, Regnault-Roger and Hamraoui [1995] demonstrated, that essential oil from the plant has a negative influence on both fertility and life span of females of the mentioned pest. Other authors also determined that wild thyme essential oil is characterized by a strong toxic effect for tobacco cutworm [Isman et al. 2001], housefly [Singh and Singh 1991] and mosquito larvae [Amer and Mehlhorn 2006]. Saroukolai et al. [2010] demonstrated, that Thymus persicus essential oils exhibit toxic effect for red flour beetle and wheat weevil, and strength of the effect increases with the increase of concentration of the used oil.

Colorado potato beetle larvae feeding on the objects, on which the $10 \%$ dry matter extract was used, already on the first date of the conducted observations were characterized by a significantly lower body weight gain than the larvae feeding in the control (Table 3). Negative values of the studied character on the analyzed object during subsequent observations demonstrate that the larvae body weight was declining during subsequent dates of conducted analyzes (similarly to the case

Table 2. The effect of water extracts prepared from dry and fresh matter of wild thyme on the leaf mass consumed by larva L4 of Colorado potato beetle [mg]. Symbols as in Table 1

\begin{tabular}{|c|c|c|c|c|c|}
\hline \multirow{2}{*}{ Object } & \multicolumn{5}{|c|}{ Time } \\
\cline { 2 - 6 } & $12 \mathrm{~h}$ & $24 \mathrm{~h}$ & $36 \mathrm{~h}$ & $48 \mathrm{~h}$ & $60 \mathrm{~h}$ \\
\hline C & $72,5^{\mathrm{b}^{\mathrm{y}}}$ & $87,2^{\mathrm{b}}$ & $101,3^{\mathrm{b}}$ & $116,3^{\mathrm{c}}$ & $135,2^{\mathrm{c}}$ \\
\hline DM 2\% & $67,3^{\mathrm{ab}}$ & $85,2^{\mathrm{ab}}$ & $95,6^{\mathrm{b}}$ & $109,6^{\mathrm{bc}}$ & $129,8^{\mathrm{bc}}$ \\
\hline DM 5\% & $65,1^{\mathrm{ab}}$ & $77,6^{\mathrm{a}}$ & $83,2^{\mathrm{a}}$ & $90,5^{\mathrm{b}}$ & $112,3^{\mathrm{ab}}$ \\
\hline DM 10\% & $56,4^{\mathrm{a}}$ & $79,5^{\mathrm{a}}$ & $81,0^{\mathrm{a}}$ & $89,9^{\mathrm{ab}}$ & $107,1^{\mathrm{a}}$ \\
\hline FM 10\% & $74,6^{\mathrm{b}}$ & $89,1^{\mathrm{b}}$ & $100,7^{\mathrm{b}}$ & $112,2^{\mathrm{bc}}$ & $125,6^{\mathrm{bc}}$ \\
\hline FM 20\% & $65,9^{\mathrm{ab}}$ & $74,3^{\mathrm{a}}$ & $79,5^{\mathrm{a}}$ & $82,3^{\mathrm{a}}$ & $101,6^{\mathrm{a}}$ \\
\hline FM 30\% & $66,3^{\mathrm{ab}}$ & $74,1^{\mathrm{a}}$ & $80,2^{\mathrm{a}}$ & $85,6^{\mathrm{a}}$ & $98,3^{\mathrm{a}}$ \\
\hline
\end{tabular}

* Values for individual terms of observations marked by different letters are statistically different $(\alpha=0.05)$

Table 3. The effect of water extracts prepared from dry and fresh matter of wild thyme on larva weight gain [mg]. Symbols as in Table 1

\begin{tabular}{|c|c|c|c|c|c|}
\hline \multirow{2}{*}{ Object } & \multicolumn{5}{|c|}{ Time } \\
\cline { 2 - 6 } & $12 \mathrm{~h}$ & $24 \mathrm{~h}$ & $36 \mathrm{~h}$ & $48 \mathrm{~h}$ & $60 \mathrm{~h}$ \\
\hline C & $10,2^{\mathrm{b}^{*}}$ & $25,3^{\mathrm{c}}$ & $26,4^{\mathrm{c}}$ & $21,8^{\mathrm{d}}$ & $16,8^{\mathrm{c}}$ \\
\hline DM 2\% & $8,3^{\text {ab }}$ & $18,9^{\mathrm{c}}$ & $19,8^{\mathrm{c}}$ & $17,3^{\mathrm{d}}$ & $15,9^{\mathrm{c}}$ \\
\hline DM 5\% & $7,8^{\mathrm{ab}}$ & $7,9^{\mathrm{b}}$ & $5,3^{\mathrm{b}}$ & $4,8^{\mathrm{c}}$ & $5,1^{\mathrm{b}}$ \\
\hline DM 10\% & $2,3^{\mathrm{a}}$ & $-5,4^{\mathrm{a}}$ & $-8,6^{\mathrm{a}}$ & $-16,2^{\mathrm{a}}$ & $-15,2^{\mathrm{a}}$ \\
\hline FM 10\% & $12,4^{\mathrm{b}}$ & $29,8^{\mathrm{c}}$ & $25,1^{\mathrm{c}}$ & $22,8^{\mathrm{d}}$ & $18,5^{\mathrm{c}}$ \\
\hline FM 20\% & $9,3^{\mathrm{b}}$ & $10,2^{\mathrm{bc}}$ & $8,3^{\mathrm{b}}$ & $-2,1^{\mathrm{b}}$ & $-7,9^{\mathrm{a}}$ \\
\hline FM 30\% & $10,2^{\mathrm{b}}$ & $5,1^{\mathrm{b}}$ & $-5,6^{\mathrm{a}}$ & $-8,6^{\mathrm{ab}}$ & $-12,6^{\mathrm{a}}$ \\
\hline
\end{tabular}

* Values for individual terms of observations marked by different letters are statistically different $(\alpha=0.05)$ 
of $30 \%$ fresh matter extract after 36, 48 and 60 hours from the establishment of the experiment and $20 \%$ fresh matter extract after 48 and 60 hours). Moreover, it was noted that extracts prepared in lower concentrations ( $5 \%$ for dry matter and $20 \%$ for fresh matter) after 24 hours also contributed to significant limitation of body weight gain and this state was maintained until the end of the experiment. Similar regularities were also observed by Rusin et al. [2016], who studied the effect of other herbaceous plant (Artemisia absinthium L.) on feeding selected crop pests. The authors demonstrated that extracts from both fresh as well as dry matter from A. absinthium L. in two highest concentrations $(20 \%$ and $30 \%$, and $5 \%$ and $10 \%$, respectively) significantly limited body weight gain of the Colorado potato beetle L4 larvae, which corroborates with the results of the present experiment in reference to wild thyme. Lamparski and Wawrzyniak [2004] also demonstrated that water extracts from dry matter of Pelargonium $\times$ hortorum Bailey in $10 \%$ concentration cause a decrease of the body weight of the Colorado potato beetle L2 larvae by over 20 $\mathrm{mg}$ in comparison to control. The same authors demonstrated in another study that water extracts from other herbaceous plants of the Geraniaceae family also can cause a decrease of the body weight in larvae of the mentioned pest [Lamparski and Wawrzyniak 2005].

Almost all used extracts inhibited the feeding of both adults and larvae of Colorado potato beetle, which is exhibited by positive values of the absolute deterrence index (Figure 1). Only in the case of imago after the use of $10 \%$ fresh matter extract, the index assumed negative values, which demonstrates stimulating effect of the used food. In the case of adult individuals, the highest values

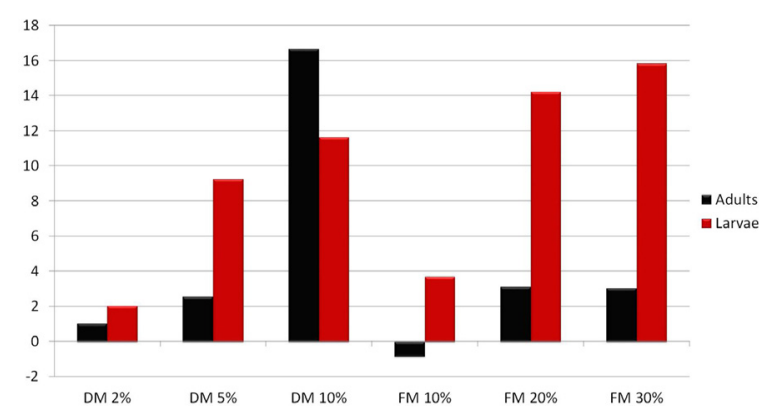

Figure 1. Absolute deterrence index, calculated according to the formula: $\mathrm{Bwd}=[(\mathrm{K}-\mathrm{T}):(\mathrm{K}+\mathrm{T})] \cdot 100$, where: $\mathrm{K}$ - mass of leaves consumed in control [mg], $\mathrm{T}-$ mass of leaves consumed in individual objects [mg]. Symbols as in Table 1 of the absolute deterrence index were assumed after the use of $10 \%$ dry matter extract, whereas for the larvae $-30 \%$ fresh matter extract (16.6 and 15.8 , respectively). Along with the increase of the extracts concentration, both from dry and fresh matter, their deterrent effect on the analyzed pests also increased. Similar regularities were observed by Rusin et al. [2015], who found that with the increase concentration of $A$. absinthium $\mathrm{L}$. water extracts, the value of the absolute deterrence index for the Colorado potato beetle L2 larvae also increases. In another study, these authors demonstrated similar relationships for the adults and L4 larvae of the analyzed pest [Rusin et al. 2016]. Wawrzyniak and Lamparski [2004, 2005, 2007] also found that water extracts prepared from dry matter of Geraniaceae plants can exhibit a deterrent effect for the adults and larvae of Colorado potato beetle.

The value of the calculated palatability index on almost all analyzed objects (except for the object, on which $10 \%$ fresh matter extract was used, for imago) assumed values lower than 1, which indicates that the leaf blade loss caused by the feeding of the Colorado potato beetle adults and larvae was lower on the objects, on which wild thyme extracts were used than in control object (Figure 2). The highest values of the analyzed index, both for imago as well as larvae were reported from the objects, on which fresh and dry matter extracts in lowest concentrations (respectively $10 \%$ and $2 \%$ ) were used. Our previous study $[2015,2016]$ demonstrated that with the increase of concentrations of water extracts prepared from fresh and dry matter of $A$. absinthium L., the palatability index value decreases for the adults and L2 and L4 larvae of Colorado potato beetle. Similar regularities were most commonly reported in

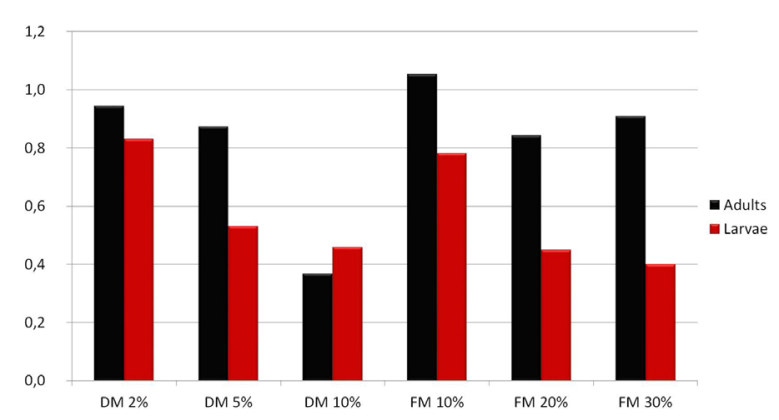

Figure 2. Palatability index, calculated as the ratio of the percentage mass of leaves consumed in individual objects to the percentage mass of leaves consumed in the control. Symbols as in Table 1 
the present experiment, both for the larvae and adults of the analyzed pest. Dankowska [2006], and Dankowska and Robak [2006] also found that an increase of concentrations of infusions from the leaves of tomato, rhododendron and $\mathrm{Eu}-$ ropean silver fir from $5 \%$ to $10 \%$, contributes to the decrease of the palatability index value by approximately 0.2 for smooth slug.

\section{CONCLUSIONS}

1. For an efficient limitation of the feeding of adult Colorado potato beetles, an extract from wild thyme dry matter with a concentration of at least $10 \%$ should be used.

2. L4 larvae appear to be considerably more susceptible to the effect of $T$. serpyllum extract. In their case, an efficient limitation of the feeding, as well as body weight gain can be obtained using extracts from both dry and fresh matter, in concentrations of over 5\% for dry matter and over $20 \%$ for fresh matter.

3. With the increase of extract concentration, the value of the calculated palatability index decreases, and the deterrence index value increases.

\section{Acknowledgements}

This Research was financed by the Ministry of Science and Higher Education of the Republic of Poland

\section{REFERENCES}

1. Abu-Darwish M.S., Abu Dieyeh Z.H., Mufeed B., Al-Tawaha A.R.M., Al-dalain S.Y.A. 2009. Trace element contents and essential oil yields from wild thyme plant (Thymus serpyllum L.) grown at different natural variable environments, Jordan. J. Food Agric. Environ., 7(3-4), 920-924.

2. Alkan M., Gökçe A., Kara K.: Antifeedant activity and growth inhibition effects of some plant extracts against larvae of Colorado potato beetle [Leptinotarsa decemlineata Say (Col: Chyrsomelidae)] under laboratory conditions. Türk. Entomol. Derg. 2015, Vol. 39(4), 345-353.

3. Amer A., Mehlhorn. 2006. Larvicidal effects of various essential oil against Aedes, Anopheles and Culex larvae (Diptera, Culicidae). Parasitol Res., 99, 466-472.

4. Dankowska E. 2006. Wykorzystanie naparów roślinnych w ograniczeniu żerowania pomrowika małego (Deroceras laeve Müll). Roczniki AR Poznań - CCCLXXIX, 3-7.

5. Dankowska E., Robak M. 2006. Wpływ naparów roślinnych na żerowanie pomrowika małego Deroceras laeve (Müll). Prog. Plant Prot./Post. Ochr. Roślin, 46(2), 338-341.

6. Isman M.B., Wan A.J., Passreiter C.M. 2001. Insecticidal activity of essential oils to the tobacco cutworm, Spodoptera litura. Fitoterapia, 72(1), 65-68.

7. Kiełczewski M., Drożdż B., Nawrot, J. 1979. Badania nad repelentami pokarmowymi trojszyka ulca (Tribolium confusum Duv.). Materiały 19 Sesji Nauk. Inst. Ochr. Roślin, 1, 367-376.

8. Kulisic T., Radonic A., Milos M. 2005. Antioxidant properties of thyme (Thymus vulgaris L.) and wild thyme (Thymus serpyllum L.) essential oils. Ital. J. Food Sci., n. 3., 17, 315-324.

9. Lamparski R., Wawrzyniak M. 2004. Effect of water extracts from geraniaceae (Geraniaceae) plants on feeding and development of Colorado potato beetle (Leptinotarsa decemlineata Say). EJPAU, 7(2).

10. Lamparski R. Wawrzyniak M. 2005. Effect of water extracts from Geraniaceae plants with adjuvant added on feeding and development of Colorado potato beetle (Leptinotarsa decemlineata Say). J. Plant Prot. Res., 45(2), 115-123.

11. Mihailovic-Stanojevic N., Belščak-Cvitanović A., Grujić-Milanović J., Ivanov M., Jovović Dj., Bugarski D., Miloradović Z. 2013. Antioxidant and antihypertensive activity of extract from Thymus serpyllum L. in experimental hypertension. Plant Foods Hum. Nutr., 68, 235-240.

12. Paaver U., Orav A., Arak E., Mäerog U., Raal A. 2008. Phytochemical analysis of the essential oil of Thymus serpyllum L. growing wild in Estonia. Nat. Prod. Res., 22(2), 108-115.

13. Popova E.N. 2014. The influence of climatic changes on range expansion and phenology of the Colorado potato beetle (Leptinotarsa decemlineata, Coleoptera, Chrysomelidae) in the territory of Russia. Entomological Review, 94(5), 643-653.

14. Raal A., Paaver U., Arak E., Orav A. 2004. Content and composition of the essential oil of Thymus serpyllum L. growing wild in Estonia. Medicina (Kaunas), 40(8), 795-800.

15. Regnault-Roger C., Hamraoui A. 1995. Comparsion of the insectidial effects of water extracted and intact aromatic plants on Acanthoscelides obtectus, a bruchid beetle pest of kidney beans. Chemoecology, 5/6(1), 1-5.

16. Regnault-Roger C., Hamraoui A., Holeman M., Theron E., Pinel R. 1993. Insecticidal effect of es- 
sential oils from mediterranean plants upon Acanthoscelides obtectus Say (Coleoptera, Bruchidae), a pest of kidney bean (Phaseolus vulgaris L.). J. Chem. Ecol., 19(6), 1233-1244.

17. Rusin M., Gospodarek J., Biniaś B. 2015. The effect of water extracts from Artemisia absinthum $\mathrm{L}$. on feeding of Leptinotarsa decemlineata Say. larvae. J. Res. Appl. Argic. Engng., 60(4), 80-83.

18. Rusin M., Gospodarek J., Biniaś B. 2016. Effect of water extracts from Artemisia absinthium L. on feeding of selected pests and their response to the odor of this plant. JCEA, 17(1), 188-206.

19. Saroukolai A.T., Moharramipour S., Meshkatalsadat M.H. 2010. Insectidal properties of Thymus persicus essential oil against Tribolium castaneum and Sitophilus oryzae. J. Pest. Sci., 83(1), 3-8.

20. Singh D., Singh A. K. 1991. Repellent and insectidal propertiesof essential oils against housefly, Musca domestica L. International Journal of Tropical Insect Science, 12(4), 487-491.
21. Sipailiene A., Venskutonis P.R., Baranauskiene R., Sarkinas A. 2006. Antimicrobial activity of commercial samples of thyme and marjoram oils. J. Essent. Oil Res., 18, 698-703.

22. Szendrei Z., Grafius E., Byrne A., Ziegler A.: Resistance to neonicotinoid insecticides in field populations of the Colorado potato beetle (Coleoptera: Chrysomelidae). Pest Manag. Sci. 2012, Vol. 68(6), 941-946.

23. Tscharntke T., Klein A.M., Kruess A., Dewenter I.S., Thies C. 2005. Landscape perspectives on agricultural intensification and biodiversity - ecosystem service management. Ecol. Letters, 8(8), 857-874.

24. Wawrzyniak M., Lamparski R. 2007. Ocena działania wyciągów z wybranych roślin zielarskich na żerowanie i rozwój stonki ziemniaczanej (Leptinotarsa decemlineata Say). Prog. Plant Prot./Post. Ochr. Roślin, 47(4), 255-258.

Pracę dofinansowano ze środków Wojewódzkiego Funduszu Ochrony Środowiska i Gospodarki Wodnej w Lublinie. 